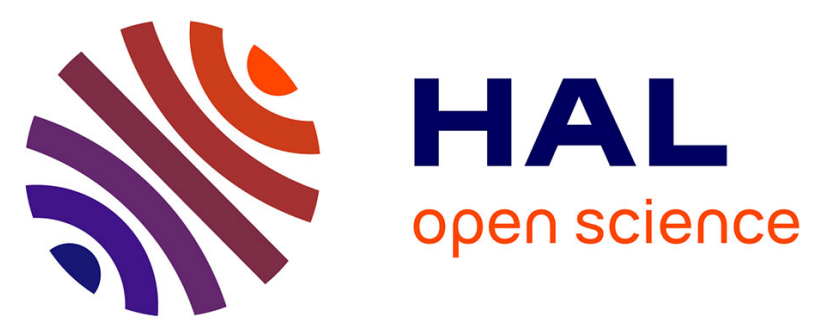

\title{
Scattering ratio profiles retrieved from ALADIN/Aeolus and CALIOP/CALIPSO lidar observations: instantaneous overlaps, statistical comparison, and sensitivity to high clouds
}

Artem Feofilov, Helene Chepfer, Vincent Noël, Marjolaine Chiriaco

\section{To cite this version:}

Artem Feofilov, Helene Chepfer, Vincent Noël, Marjolaine Chiriaco. Scattering ratio profiles retrieved from ALADIN/Aeolus and CALIOP/CALIPSO lidar observations: instantaneous overlaps, statistical comparison, and sensitivity to high clouds. EGU General Assembly 2021, Apr 2021, online, France. 10.5194/egusphere-egu21-4746 . hal-03201005

\section{HAL Id: hal-03201005 \\ https: / hal.sorbonne-universite.fr/hal-03201005}

Submitted on 17 Apr 2021

HAL is a multi-disciplinary open access archive for the deposit and dissemination of scientific research documents, whether they are published or not. The documents may come from teaching and research institutions in France or abroad, or from public or private research centers.
L'archive ouverte pluridisciplinaire HAL, est destinée au dépôt et à la diffusion de documents scientifiques de niveau recherche, publiés ou non, émanant des établissements d'enseignement et de recherche français ou étrangers, des laboratoires publics ou privés. 
EGU21-4746, updated on 17 Apr 2021

https://doi.org/10.5194/egusphere-egu21-4746

EGU General Assembly 2021

(c) Author(s) 2021. This work is distributed under

the Creative Commons Attribution 4.0 License.

\title{
Scattering ratio profiles retrieved from ALADIN/Aeolus and CALIOP/CALIPSO lidar observations: instantaneous overlaps, statistical comparison, and sensitivity to high clouds
}

\author{
Artem Feofilov ${ }^{1}$, Helene Chepfer ${ }^{1}$, Vincent Noel $^{2}$, and Marjolaine Chiriaco ${ }^{3}$ \\ ${ }^{1}$ LMD / Sorbonne University / Ecole Polytechnique / CNRS, Dynamic Meteorology Laboratory (LMD), Palaiseau Cedex, France \\ (artem.feofilov@Imd.polytechnique.fr) \\ ${ }^{2}$ Laboratoire d'Aerologie, LAERO/OMP, Toulouse, France \\ ${ }^{3}$ LATMOS/OVSQ, Guyancourt, France
}

Clouds and aerosols play an important role in the Earth's energy budget through a complex interaction with solar, atmospheric, and terrestrial radiation, and air humidity. Optically thick clouds efficiently reflect the incoming solar radiation and, globally, clouds are responsible for about two thirds of the planetary albedo. Thin cirrus trap the outgoing longwave radiation and keep the planet warm. Aerosols scatter or absorb sunlight depending on their size and shape and interact with clouds in various ways.

Due to the importance of clouds and aerosols for the Earth's energy budget, global satellite observations of their properties are essential for climate studies, for constraining climate models, and for evaluating cloud parameterizations. Active sounding from space by lidars and radars is advantageous since it provides the vertically resolved information. This has been proven by CALIOP lidar which has been observing the Earth's atmosphere since 2006. Another instrument of this kind, CATS lidar on-board ISS provided measurements for over 33 months starting from the beginning of 2015. The ALADIN lidar on-board ADM/Aeolus has been measuring horizontal winds and aerosols/clouds since August 2018. More lidars are planned - in 2022, the ATLID/EarthCare lidar will be launched and other space-borne lidars are in the development phase.

In this work, we compare the scattering ratio products retrieved from ALADIN and CALIOP observations. The former is aimed at $35 \mathrm{deg}$ from nadir, it measures the atmospheric backscatter at $355 \mathrm{~nm}$ from nadir, is capable of separating the molecular and particular components (HSRL), and provides the profiles with a vertical resolution of $\sim 1 \mathrm{~km}$ up to $20 \mathrm{~km}$ altitude. The latter, operating at $532 \mathrm{~nm}$ is aimed at $3 \mathrm{deg}$ from nadir and measures the total backscatter up to $40 \mathrm{~km}$. Its natural vertical resolution is higher than that of ALADIN, but the scattering ratio product used in the comparison is provided at $\sim 0.5 \mathrm{~km}$ vertical grid.

We have performed a search of nearly simultaneous common volume observations of atmosphere by these two instruments for the period from 28/06/2019 through 31/12/2019 and analyzed the collocated data. We present the zonal averages of scattering ratios as well as the 
instantaneous profile comparisons and the statistical analysis of cloud detection, cloud height agreement, and temporal evolution of these characteristics.

The preliminary conclusion, which can be drawn from this analysis, is that the general agreement of scattering ratio profiles retrieved from ALADIN and CALIOP observations is good up to 6-7 km height whereas in the higher atmospheric layers ALADIN is less sensitive to clouds than the CALIOP. This lack of sensitivity might be compensated by further averaging of the input signals and/or by an updating of the retrieval algorithms using the collocated observations dataset provided in the present work. 